\title{
PENGARUH MOTIVASI KERJA TERHADAP KINERJA PEGAWAI PT. PLN BATAM
}

\section{THE EFFECT OF WORK MOTIVATION ON EMPLOYEE PERFORMANCE OF PT. PLN BATAM}

\author{
Jayanti Ardhani $1^{1}$, Sri Langgeng Ratnasari ${ }^{2}$ \\ ${ }^{1}$ (Prodi Pascasarjana Universitas Riau Kepulauan, Indonesia) \\ ${ }^{2}$ (Prodi Pascasarjana Universitas Riau Kepulauan, Indonesia) \\ j.ardhani@gmail.com ${ }^{1}$,sarisucahyo@gmail.com ${ }^{2}$
}

\begin{abstract}
Abstrak
Kinerja karyawan merupakan factor penting pada organisasi, karena kinerja pegawai secara keseluruhan menjadi kinerja organisasi. Penelitian ini bertujuan untuk mengetahui pengaruh motivasi kerja terhadap kinerja pegawai PT. PLN Batam. Metode penelitian ini menggunakan metode kuantitatif deskriptif, dengan populasi karyawan PT. PLN Batam sebanyak 105 pegawai. Teknik samplingnya menggunakan teknik sensus, dimana seluruh populasi diteliti. Teknik analisis statistik yang digunakan adalah SPPS dengan Regresi Linier Berganda. Berdasarkan hasil analisis dan pembahasan, maka menghasilkan kesimpulan penelitian bahwa Motivasi Kerja berpengaruh secara signifikan terhadap Kinerja Pegawai PT. PLN Batam.
\end{abstract}

Kata kunci: Motivasi Kerja; Kinerja Pegawai

\begin{abstract}
Employee performance is an important factor in the organization, because overall employee performance becomes organizational performance. This study aims to determine the effect of work motivation on the performance of employees of PT. PLN Batam. This research method uses descriptive quantitative method, with a population of employees of PT. PLN Batam as many as 105 employees. The sampling technique uses census techniques, where the entire population is examined. The statistical analysis technique used is SPPS with Multiple Linear Regression. Based on the results of the analysis and discussion, the research concludes that Work Motivation significantly influences the Performance of PT. PLN Batam.
\end{abstract}

Keywords: Work Motivation, Employee Performance, Organizational Behavior

\section{PENDAHULUAN}

Sumber Daya Manusia merupakan modal utama dalam menunjang keberhasilan perusahaan apabila dikelola dengan baik, dan dengan dukungan sumber daya manusia yang berkualitas akan sejalan dengan terwujudnya visi dan misi perusahaan. Sumber daya manusia dapat dikatakan berkualitas apabila memiliki kinerja yang baik dengan menyelesaikan seluruh kewajibannya sesuai dengan hasil yang telah ditetapkan. Apabila perusahaan tidak memiliki sumber daya manusia yang berkualitas, tentu saja akan berdampak pada kinerja perusahaan seiring dengan berjalannya waktu, dikarenakan perkembangan zaman yang dinamis. 
Kinerja pada dasarnya adalah apa yang dilakukan atau tidak dilakukan oleh pegawai dalam mengemban pekerjaannya (Mathis dkk, 2014). Setiap perusahaan berusaha untuk meningkatkan kinerja pegawainya demi tercapainya tujuan yang telah ditetapkan oleh perusahaan. Berbagai cara dapat ditempuh perusahaan dalam meningkatkan kinerja melalui motivasi kerja yang sesuai dengan harapan pegawai.

\section{Tujuan Penelitian}

Berdasarkan latar belakang dan rumusan masalah yang ada, maka penelitian ini dilakukan dengan tujuan untuk menganalisis pengaruh motivasi kerja terhadap kinerja pegawai PT. PLN Batam.

\section{TELAAH PUSTAKA}

\section{Motivasi Kerja}

Motivasi kerja adalah sekumpulan kekuatan energetik yang dimulai baik dari dalam maupun diluar pekerja, dimulai dari usaha yang berkaitan dengan pekerjaan, dan mempertimbahkan arah, intensitas dan ketekunannya (Wibowo, 2015). Menurut Kreitner dan Kinicki (2014) motivasi adalah kumpulan proses psikologis yang menyebabkan pergerakan mengarahan, dan kegigihan dari sikap sukarela yang mengarah pada tujuan.

\section{Kinerja Pegawai}

Kinerja pegawai adalah mengacu pada tingkat pemenuhan tugas yang membentuk pekerjaan karyawan (Rue, 2016). Penilaian kinerja memiliki peranan yang sangat penting dalam peningkatan motivasi di tempat kerja. Penilaian hendaknya memberikan suatu gambaran akurat mengenai prestasi kerja. Menurut Mondy dkk (2016) mengemukakan bahwa manajemen kinerja adalah proses berorientasi tujuan yang diarahkan untuk memastikan bahwa proses-proses keorganisasian ada pada tempatnya untuk memaksimalkan produktivitas para karyawan, tim, dan akhirnya organisasi perusahaan.

\section{Hipotesis}

Berdasarkan kerangka Pemikiran teoritis, penelitian terdahulu, dan rumusan masalah, maka penelitian ini dapat di rumuskan hipotesis sebagai berikut: Motivasi kerja berpengaruh terhadap kinerja pegawai PT. PLN Batam

\section{METODE PENELITIAN}

\section{Objek Penelitian}

Objek penelitian ini adalah pegawai PT. PLN Batam Servis Business Unit, sebanyak 105 pegawai. 


\section{Populasi dan Sampel}

Populasi dalam penelitian adalah sebanyak 105 pegawai yang diambil dari Services Business Unit PT. PLN Batam. Teknik pengambilan sampel dalam penelitian ini dengan menggunakan teknik sensus, sampel penelitian adalah seluruh pegawai, sebanyak 105 pegawai.

\section{METODE ANALISIS DATA}

\section{Uji Validitas}

Uji validitas adalah suatu ukuran yang menunjuk tingkatan kevalidan dari instrumen yang digunakan untuk mengumpulkan data. Suatu instrumen dikatakan valid apabila instrumen tersebut dapat mengukur apa yang seharusnya diukur dan dapat mengungkapkan data dari variabel yang diteliti secara tepat.

Uji validitas dilakukan dengan membandingkan nilai $r$ hitung dengan nilai rtabel pada taraf signifikansi 0.05 , yaitu:

1. Jika $r$ hitung $>\mathrm{r}$ tabel 0.05 dan nilai positif, maka pertanyaan atau indikator pada kuesioner tersebut adalah valid.

2. Jika $r$ hitung $<\mathrm{r}$ tabel 0.05 maka pertanyaan tersebut dinyatakan tidak valid.

\section{Uji Reliabilitas}

Tujuan dari reliabilitas adalah untuk mengetahui sejauh mana suatu hasil pengukuran relatif konsisten apabila pengukuran diulangi dua kali atau lebih. Pengukuran reliabilitas menggunakan teknik belah dua, yaitu membagi pertanyaan yang valid menjadi dua belah antara kelompok pada nomor genap dengan kelompok pada nomor ganjil. Apabila korelasi 0,6 atau lebih maka dikatakan item tersebut memberikan tingkat reliabel yang cukup, sedangkan apabila nilai korelasi dibawah 0,6 maka dikatakan item tersebut kurang reliabel.

\section{Uji Normalitas Data}

Uji normalitas ini bertujuan untuk menguji apakah dalam model regresi, variabel dependen dan variabel independen keduanya memiliki distribusi normal atau tidak. Uji normalitas data dalam penelitian ini menggunakan Kolmogorov-Smirnov. Tes untuk masingmasing variabel. Hipotesis yang digunakan adalah:

Ho $=$ Data residual terdistribusi normal

$\mathrm{Ha}=$ Data residual tidak terdistribusi normal

Pengujian normalitas dilakukan dengan melihat nilai 2-tailedsignificant. Jika data memiliki tingkat signifikansi lebih besar dari 0,05 atau 5\%, maka dapat disimpulkan bahwa H0 diterima, sehingga dikatakan data berdistribusi normal. 


\section{Uji Asumsi Klasik}

Uji asumsi klasik yang dilakukan oleh peneliti menggunakan regresi linier berganda yaitu:

a. Uji multikolinearitas.

b. Uji heteroskedastisitas.

\section{Uji Multikolinearitas}

Uji multikolinearitas adalah untuk melihat ada atau tidaknya korelasi yang tinggi antara variabel-variabel bebas dalam suatu model regresi linear berganda. Jika ada korelasi yang tinggi diantara variabel-variabel bebasnya, maka hubungan antara variabel bebas terhadap variabel terikatnya menjadi terganggu. Alat statistik yang sering digunakan untuk menguji gangguan multikolinearitas adalah dengan Variance Inflation Factor (VIF), korelasi pearson antara variabel-variabel bebas atau melihat eigenvalues dan Condition Indeks (CI).

\section{Uji Heterokedastisitas}

Pengujian heteroskedastisitas dilakukan dalam sebuah model regresi dengan tujuan bahwa apabila suatu regresi tersebut terjadi ketidaksamaan varians dari residual dan pengamatan. Jika varian dari residual satu pengamatan ke pengamatan yang lain tetap, maka disebut dengan homoskedastisitas dan jika terdapat perbedaan, maka disebut heteroskedastisitas.

\section{Analisis Regresi Linear Berganda}

Analisis regresi linier berganda yaitu suatu analisis yang bertujuan untuk menguji motivasi kerja berpengaruh terhadap kinerja pegawai.

$\mathrm{Y}=\mathrm{b} 0+\mathrm{b} 1 \mathrm{X} 1+\mathrm{e}$

Di mana :

$\mathrm{Y}=$ Kinerja karyawan

X1 = Motivasi Kerja

b1 = Koefisien regresi yang hendak diamati.

\section{Uji T}

Uji T digunakan untuk mengetahui apakah masing-masing variabel bebasnya secara sendiri-sendiri berpengaruh secara signifikan terhadap variabel terikatnya. Dimana $\mathrm{t}$ tabel $>\mathrm{t}$ hitung, H0 diterima. Dan jika $\mathrm{t}$ tabel $<\mathrm{t}$ hitung, maka H1 diterima, begitupun jika sig > ó $(0,05)$, maka H0 diterima H1 ditolak dan jika sig < ́́ $(0,05)$, maka H0 ditolak $\mathrm{H} 1$ diterima. 


\section{Hasil Penelitian dan Pembahasan Analisis Deskriftif}

\section{Data Responden berdasarkan Jenis Kelamin}

\section{Tabel 1 Data Responden Berdasarkan Jenis Kelamin}

\begin{tabular}{clcc}
\hline No. & Jenis Kelamin & Frekuensi & Prosentase \\
\hline 1 & Pria & 67 & $63,8 \%$ \\
2 & Wanita & 38 & $36,2 \%$ \\
& Jumlah & 105 & $100 \%$
\end{tabular}

Sumber: Hasil Penelitian, 2019

Berdasarkan Tabel 1 dapat digambarkan bahwa jumlah responden sebanyak 105, dengan jumlah responden pria sebanyak 67 orang dan responden perempuan sebanyak 38 orang. Dengan demikian, hal ini menunjukkan bahwa sebagian besar responden berjenis kelamin pria.

\section{Responden Menurut Usia}

Tabel 2 Responden Menurut Usia

\begin{tabular}{clcc}
\hline No. & Usia & Frekuensi & Prosentase \\
\hline 1 & 20-30 tahun & 30 & $28,6 \%$ \\
2 & 31-40 tahun & 47 & $44,8 \%$ \\
3 & 41-50 tahun & 23 & $21,9 \%$ \\
4 & $>51$ tahun & 5 & $4,7 \%$ \\
& Jumlah & 105 & $100 \%$ \\
\hline
\end{tabular}

Sumber: Hasil Penelitian, 2019

Berdasarkan Tabel 2 diperoleh bahwa responden yang berusia 20-30 tahun sebanyak 30 orang, responden dengan usia 31-40 tahun sebanyak 47 orang, responden dengan usia 41-50 tahun sebanyak 23 orang dan responden dengan usia diatas 51 tahun sebanyak 5 orang. Dengan demikian, hal ini menunjukkan bahwa sebagian besar responden berusia 31- 40 tahun dan 41-50 tahun. 


\section{Responden Menurut Pendidikan}

Tabel 3 Responden Menurut Pendidikan

\begin{tabular}{|c|l|c|c|}
\hline No. & Pendidikan & Frekuensi & Prosentase \\
\hline 1 & SLTA/SMK & 10 & $9,5 \%$ \\
\hline 2 & D3 (Diploma) & 21 & $20,0 \%$ \\
\hline 3 & S1 (Sarjana) & 68 & $64,8 \%$ \\
\hline 4 & S2 (Magister) & 6 & $5,7 \%$ \\
\hline
\end{tabular}

Sumber: Hasil Penelitian, 2019

Berdasarkan Tabel 3 diperoleh hasil responden yang berpendidikan SLTA/SMK sebanyak 10 orang, responden yang berpendidikan D3 sebanyak 21 orang, responden yang berpendidikan S1 sebanyak 68 dan responden yang berpendidikan S2 sebanyak 6 orang. Dengan demikian, hal ini menunjukkan bahwa responden sebagian besar berpendidikan S1(Sarjana).

\section{Responden Menurut Lama Bekerja}

Tabel 4 Responden Menurut Lama Bekerja

\begin{tabular}{clcc}
\hline No. & Lama Bekerja & Frekuensi & Prosentase \\
\hline 1 & $<1$ tahun & 3 & $2,9 \%$ \\
2 & $1-2$ tahun & 12 & $11,4 \%$ \\
3 & $3-5$ tahun & 9 & $8,6 \%$ \\
4 & $>6$ tahun & 81 & $77,1 \%$ \\
& Jumlah & 105 & $100 \%$ \\
\hline
\end{tabular}

Sumber: Hasil Penelitian, 2019

Berdasarkan Tabel 4 diatas diperoleh hasil bahwa responden yang lama bekerja $<1$ tahun sebanyak 3 orang, lama bekerja 1-2 tahun sebanyak 12 orang, lama bekerja 3-5 tahun sebanyak 9 orang, dan lama bekerja $>6$ tahun sebanyak 81 orang. Dengan demikian, hal ini menunjukkan bahwa sebagian besar responden lama bekerja $>6$ tahun. 


\section{Uji Validitas}

Uji validitas adalah prosedur untuk memastikan apakah kuesioner yang akan dipakai untuk mengukur variabel penelitian valid atau tidak. Kuesioner dikatakan valid apabila dapat mempresentasikan atau mengukur apa yang hendak diukur (variabel penelitian). Dengan kata lain validitas adalah ukuran yang menunjukkan kevalidan dari suatu instrumen yang telah ditetapkan (Gunawan, 2013).

Pada penelitian ini tingkat alfa yang digunakan adalah 5\% (0,05). Pada alfa 5\% derajat bebas $(\mathrm{N}-2)$ bahwa nilai $\mathrm{r}$ dalam tabel sebesar 0,1918. Jika nilai $r$ hitung $>\mathrm{r}$ tabel dan nilai signifikan berada pada 0,05 maka dikatakan valid.

Pengujian ini memiliki 1variabel bebas yaitu Motivasi Kerja (X1), serta 1 variabel terikat yaitu Kinerja Karyawan (Y). Hasil uji variabel terhadap item pernyataan dalam penelitian valid.

\section{Uji Reliabilitas}

\section{Tabel 5 Hasil Uji Reliabilitas Variabel}

\begin{tabular}{cccc}
\hline Variabel & Cronbach & Koefisien & \\
& Alpha & Alpha & Status \\
\hline Motivasi Kerja (X4) & 0,922 & 0,6 & Reliabel \\
Kinerja Pegawai (Y) & 0,854 & 0,6 & Reliabel \\
\hline
\end{tabular}

Sumber: Hasil Penelitian, 2019

Pada Tabel 5 dapat dilihat bahwa R Alpha masing-masing variabel X1 dan Y lebih besar dari 0,60 dimana $\mathrm{R}$ Alpha Motivasi Kerja 0,922 dan Kinerja Pegawai 0,854. Berdasarkan hasil uji validitas, maka dapat disimpulkan bahwa data yang diuji adalah reliabel. 


\section{Uji Normalitas}

\section{Hasil Uji Normalitas}

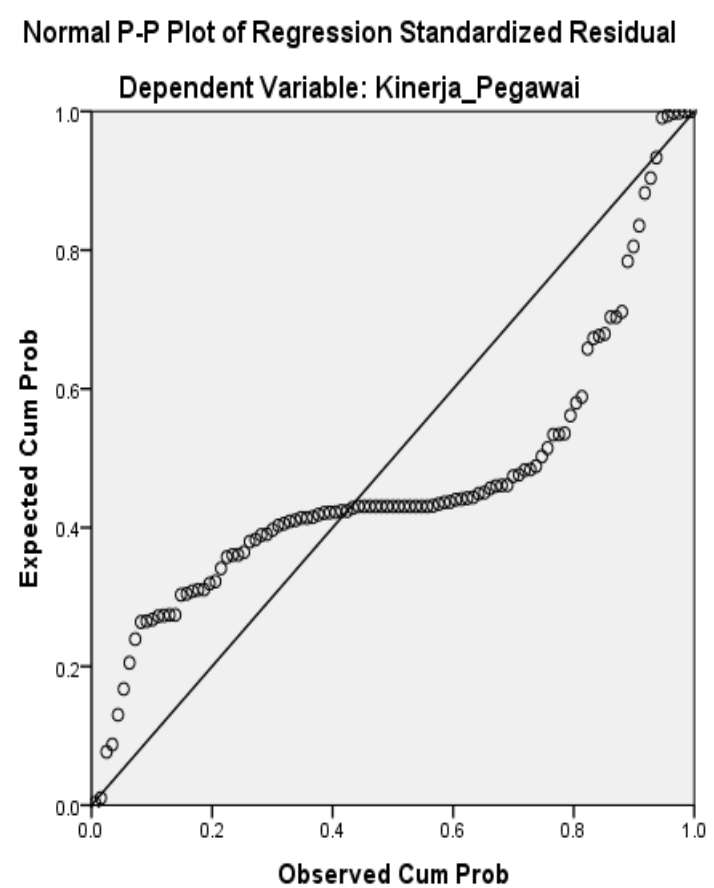

Gambar 1 Hasil Uji Normalitas

Gambar 1 merupakan hasil uji normalitas, dimana dapat dilihat bahwa titik-titik data menyebar jauh dari garis diagonal dan tidak mengikuti arah garis diagonal, sehingga model regresi tidak memenuhi asumsi normalitas.

\section{Uji Multikolinearitas}

Berdasarkan hasil uji multikolonieritas adalah 3,762 dan 3,524 sehingga dapat disimpulkan bahwa tidak terjadi gejala multikolinearitas antar variabel bebas karena VIF lebih kecil dari 10,00 sehingga semua variabel dinyatakan variabel yang saling independen. 


\section{Uji Heterokedastisitas}

\section{Hasil Uji Heterokedastisitas}

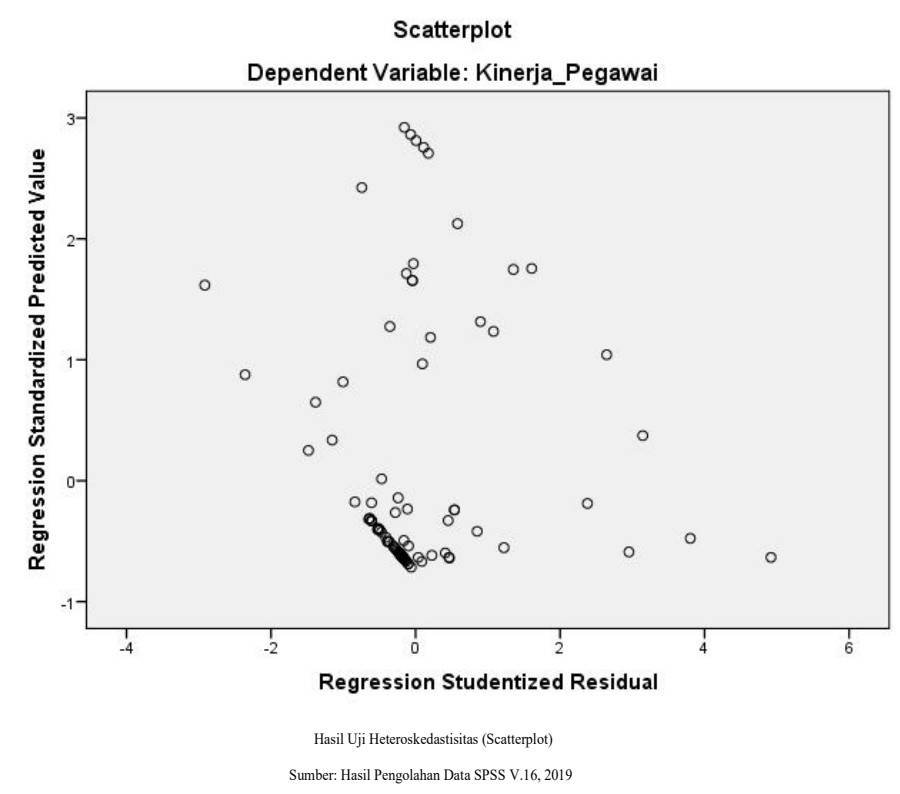

Gambar 2 Hasil Uji Heteroikedasitas

Sumber: Hasil Penelitian, 2019

Pada Gambar 2 dapat dilihat titik-titik menyebar secara acak baik diatas maupun dibawah angka nol dan tidak membentuk pola maka dapat disimpulkan tidak terjadi multikulinearitas pada penelitian.

\section{PEMBAHASAN}

\section{Pengaruh Motivasi Kerja Terhadap Kinerja Pegawai PT. PLN Batam}

Berdasarkan analisis data dan pengujian hipotesis kedua dapat dibuktikanbahwa melalui hasil olah data SPSS diperoleh nilai t hitung untuk variabel Motivasi Kerja (X4) sebesar 7,461 dengan taraf signifikan sebesar 0,000. Tingkat signifikan tersebut memenuhi tingkat signifikan yang telah ditentukan sebelumnya, yaitu sebesar 0,05. Dengan demikian Motivasi Kerja berpengaruh secara signifikan terhadap Kinerja Pegawai PT. PLN Batam.

\section{KESIMPULAN DAN SARAN}

\section{Kesimpulan}

Berdasarkan dari hasil penelitian dan pembahasan yang telah dijelaskan peneliti pada bab sebelumnya, maka dapat disimpulkan bahwa: Motivasi Kerja berpengaruh secara signifikan terhadap Kinerja Pegawai PT. PLN Batam 


\section{Saran}

Berdasarkan kesimpulan yang diperoleh dalam penelitian ini, maka diajukan saransaran sebagai pelengkap terhadap hasil penelitian dan rekomendasi yang dapat diberikan untuk penelitian yang akan datang sebagai berikut:

1. Bagi perusahaan diharapkan penelitian ini dapat dijadikan sebagai bahan masukan ataupun bahan pertimbangan untuk manajemen atas untuk dapat meningkatkan kinerja pegawai PT. PLN Batam.

2. Bagi akademisi diharapkan penelitian ini dapat dijadikan referensi untuk penelitian selanjutnya sehingga mendapatkan hasil yang lebih baik.

\section{REFERENSI}

Annual Report PT. PLN Batam. 2016. Batam : PT. PLN Batam.

Adyasa, dkk. 2013. Hubungan Gaya Kepemimpinan dan Motivasi dengan Kinerja Pegawai Biro Tata Pemerintahan Sekretariat Daerah Provinsi Jawa Tengah : Jurnal Volume 2, Nomor 1, 2013.

Arikunto, S. 2013. Prosedur Penelitian: Suatu Pendekatan Praktik. Jakarta: Rineka Cipta.

Banni, dkk. 2013. Pengaruh Disiplin dan Motivasi Terhadap Kinerja Pegawai PT . PLN (Persero) Wilayah Kalimantan Timur Area Samarinda : Jurnal Publikasi Ilmiah, Maret 2013.

Bernardin, H.John and Russel. 2014. Human Resource Management. New York: McGrawHill.

Djuremi, Leonardo Budi Hasiholan, Maria Magdalena Minarsih. 2016. Pengaruh Lingkungan Kerja, Budaya Organisasi, dan Kepemimpinan Terhadap Kinerja Pegawai Pada Dinas Pasar Kota Semarang, Journal of Management, Volume 2, No. 2, Maret 2016.

Fahmi, Irham. 2014. Manajemen Teori, Kasus, dan Solusi. Bandung: Alfabeta.

Feriyanto, Andri. 2015. Pengantar Manajemen. Kebumen: Mediatera.

Ghozali, Imam. 2013. Aplikasi Analisis Multivariate dengan Program SPSS. Semarang: Badan Penerbit Universitas Diponogoro.

Gunawan, Iman. 2013. Metode Penelitiaan Kualitatif :Teori dan Pratilik. Jakarta: Bumi Aksara. 
Hasan, Djufri., Syamsul Bachri dan Bakri Hasanuddin. Pengaruh Kepemimpinan Kepala Sekolah dan Lingkungan Kerja Fisik terhadap Kinerja Guru SMA Negeri 1 Ampana : Jurnal, Volume 5, Nomor 10, Oktober 2017.

Hasibuan, Malayu. S.P 2014. Manajemen Sumber Daya Manusia (Edisi Revisi). Jakarta: Bumi Aksara.

Hasibuan, Malayu S.P. 2016. Manajemen Sumber Daya Manusia. Jakarta: PT. Bumi Aksara.

Haming, M., \& Nurnajamuddin, M. 2014. Manajemen Produksi Modern Operasi Manufaktur dan Jasa. Jakarta: Bumi Aksara.

Ismaniar, Hetty. 2015. Manajemen Unit Kerja. Yogyakarta: Deepubish.

Kuncoro, Mudrajad. 2013. Metode Riset untuk Bisnis dan Ekonomi. Jakarta: Erlangga.

Kotter, John P., dan James L. Heskett 2013. Accelerate: Building Strategic Agility for a Faster- Moving World. New York: Free Press.

Kreitner, R. dan Kinicki, A. 2014. Perilaku Organisasi - Organizational Behaviour. Jakarta: Salemba Empat.

Maabuat, Edward S. 2016. Pengaruh Kepemimpinan, Orientasi Kerja, dan Budaya Organisasi terhadap Kinerja Pegawai (Studi Pada Dispenda Sulut UPTD Tondano) : Jurnal Berkala Ilmiah, Volume 16, No 01, Tahun 2016.

Mangkunegara. 2014. Manajemen Sumber Daya Manusia Perusahaan. Bandung: PT. Remaja Rosdakarya.

Masambe, Fince, Agus S. Soegoto, dan Jacky Sumarauw. 2015. Pengaruh Gaya Kepemimpinan, Budaya Organisasi dan Inovasi Pemimpin terhadap Kinerja Karyawan Daihatsu Kharisma Manado : Jurnal EMBA, Vol. 3, No. 3, Sept. 2015.

Mathis, Robert L. dan John H. Jackson. 2014. Manajemen Sumber Daya Manusia. Jakarta: Salemba Empat.

Meutia, dkk. 2016. Pengaruh Kompensasi dan Kompetensi dengan Motivasi Sebagai Intervening dalam Meningkatkan Kinerja : Jurnal Manajemen, Volume XX, No. 03, Oktober 2016.

Mondy, R. Wayne, Noe Robert M., 2016. Human Resource Management, Penterjemah Bayu Airlangga, M.M. Jakarta: Erlangga.

Pebrianti, Tutik. 2013. Pengaruh Disiplin dan Motivasi Kerja Terhadap Kinerja Pegawai di Lingkungan Biro Humas dan Protokol Sekretariat Daerah Provinsi Sumatera Selatan: Jurnal Edisi ke-IX, Mei 2013. 
Priansa, Donni Juni. 2014. Perencanaan dan Pengembangan Sumber Daya Manusia. Bandung: Alfabeta.

Priyatno, Duwi. 2014. SPSS 22 Pengolahan Data Terpraktis. Yogyakarta: Andi Offset.

Pangandaheg, Steven Christian., Ivonne S. Saerang, Sjendry S.R. Loindong. 2017. Pengaruh Gaya Kepemimpinan dan Budaya Organisasi Terhadap Kinerja Pegawai Dinas Koperasi dan UMKM Provinsi Sulawesi Utara : Jurnal EMBA, Vol. 5, No. 2, Juni 2017.

Putri, Igar Arwit., 2018. Pengaruh Kepemimpinan, Budaya Organisasi dan Motivasi terhadap Kinerja Karyawan Perusahaan Benih di PT. TAP Demak : Jurnal, Universitas Brawijaya.

Pomalingo, Silvya L Mandey, Yantje Uhing. 2015. Pengaruh Disiplin Kerja, Kompetensi, dan Motivasi terhadap Kinerja Pegawai pada Kantor Badan Penanggulangan Bencana Daerah Provinsi Sulawesi Utara : Jurnal Berkala Ilmiah, Volume 15, No. 05,2015 .

Robbins, S.P dan Timothy A. Judge. 2015. Perilaku Organisasi, Edisi 16. Jakarta: Salemba Empat.

Syahron Lubis. 2011. Metodologi Penelitian Pendidikan. Padang : Sukabina Press.

Sugiyono. 2013. Metode Penelitian Kuantitatif, Kualitatif dan R\&D. Bandung: Alfabeta.

Sujarweni, Wiratna. 2014. Metodologi penelitian: Lengkap, praktis dan mudah dipahami. Yogyakarta: PT Pustaka Baru.

Sugiyono. 2014. Metode Penelitian Pendidikan Pendekatan Kuantitatif, Kualitatif Dan R\&D. Bandung: Alfabeta.

Simamora. 2014. Membuat Karyawan Lebih Produktif Dalam Jangka Panjang (Manajemen SDM). Yogyakarta: STIE YKPN.

Sutikno, Sobry M. 2014. Pemimpin dan Gaya Kepemimpinan, Edisi Pertama. Lombok: Holistica.

Sari, Yanti Komala. 2014. Pengaruh Kepemimpinan, Motivasi dan Disiplin Kerja Terhadap Kinerja Karyawan pada PT. Patra Komala di Dumai : Jurnal Manajemen Bisnis, Vol VI. Mei 2014.

Sugiyono, Susanto. 2015. Cara Mudah Belajar SPSS dan Lisrel Teori dan Aplikasi untuk Analisis Data Penelitian. Bandung: Alfabeta.

Sutrisno. 2015. Manajemen Sumber Daya Manusia. Jakarta: Kencana Prenadamedia. 
Simamora. 2015. Manajemen Sumber Daya Manusia. Yogyakarta: STIE. YKPN.

Sugiyono. 2016. Metode Penelitian Manajemen. Bandung: Alfabeta.

Schuler, Jackson. 2016. Pengelolaan Sumber Daya Manusia. Jakarta: Salemba Empat.

Sutrisno, Edy. 2016. Manajemen Sumber Daya Manusia. Jakarta : Prenada Media Group.

Sulistyo, Bambang., Maria Magdalena Minarsih, M Mukeri Warso. 2016. Pengaruh Pendidikan dan Latihan Profesi Guru (PLPG), Kedisiplinan Guru, dan Kompetensi Guru Terhadap Kinerja Guru di SMP Masehi Jepara: Journal of Management, Volume 2, No.2, Maret 2016.

Sugiyono. 2017. Statistika Untuk Penelitian. Bandung: Alfabeta.

Siswanto, H.B. 2017. Pengantar Manajemen. Jakarta: PT Bumi Aksara.

Supomo, Nurhayati. 2018. Manajemen Sumber Daya Manusia. Bandung: Yrama Widya.

Tersiana, Andra. 2018. Metode Penelitian. Yogyakarta: Tersiana.

Tsani, Ahrul. 2013. Pengaruh Kompetensi, Penempatan Kerja dan Motivasi terhadap Kinerja Pegawai Sekretariat Jenderal Kementrian Luar Negeri : Jurnal MIX, Voluem III, No. I, Februari 2013.

Togas, Franky Bastian., Yantje Uhing. 2015. Pengaruh Lingkungan Kerja, Motivasi, dan Keterampilan terhadap Prestasi Kerja Karyawan pada Bank BRI Cabang Manado : Jurnal EMBA, Volume 3, No. 3, September 2015.

Utari, 2015. Pengaruh Motivasi, Kepemimpinan, dan Kedisiplinan Terhadap Kinerja Pegawai

(Studi Kasus pada Dinas Pendapatan Pengelolaan Keuangan dan Aset Daerah Wonogiri) : Naskah Publikasi, Universitas Muhammadiyah Surakarta.

Wibowo. 2014. Manajemen Kinerja. Jakarta: Rajawali Pers.

Wibowo. 2015. Perilaku Dalam Organisasi. Jakarta: PT Raja Grafindo Persada.

Wibowo. 2016. Manajemen Kinerja. Jakarta: PT. Raja Grafindo Persada.

Widodo, 2013. Analisis Pengaruh antara Faktor Pendidikan, Motivasi, dan Budaya Kerja Terhadap Kinerja Pegawai dalam Pelaksanaan Pelayanan Publik (Studi Kasus pada Badan Pelayanan Perijinan Terpadu Kota Pontianak) : Jurnal, Universitas Tanjungpura Pontianak.

Wungubelen, 2014. Pengaruh Kepemimpinan dan Disiplin Terhadap Kinerja Pegawai pada Inspektorat Kabupaten Flores Timur : Jurnal Administrasi Publik dan Birokrasi, Vol. 1 , No. 1, 2014. 
Yamin, Fadel. 2017. Pengaruh Budaya Organisasi dan Komitmen Organisasi terhadap Kinerja Karyawan dengan Kepuasan Kerja Karyawan sebagai Intervening (Studi Kasus pada Bank Mega Branch Trans Studio di Makassar) : Jurnal, Universitas Islam Indonesia.

Yukl, Gary. 2015. Leadership In Organization, Seventh Edition-Kepemimpinan Dalam Organisasi. Jakarta: Indeks.

Yuiarsih, Sri., Leonardo Budi Hasiholan, Yulianeu. 2017. Pengaruh Kepemimpinan, Motivasi, dan Lingkungan Kerja Terhadap Kinerja Pegawai pada PERUM DAMRI Kantor Divisi Regional II Semarang : Jurnal Ilmiah Manajemen, 2017. 